\title{
Estimating propagule pressure and viability of diatoms detected in ballast tank sediments of ships arriving at Canadian ports
}

\author{
Maria Célia Villac* ${ }^{*}$ Irena Kaczmarska \\ Department of Biology, Mount Allison University, 63B York St., Sackville, New Brunswick, E4L 1G7, Canada
}

\begin{abstract}
This research uses the concept of propagule pressure (number of individuals introduced and number of introduction attempts) to investigate human-mediated bioinvasion patterns. We quantified diatoms in the sediments of ballast tanks of commercial ships arriving on both Canadian coasts during 2007 to 2009. Diatom cell concentrations varied from non-detected to $10^{5} \mathrm{cells} \mathrm{g}^{-1}$ wet weight $\left(10^{11}\right.$ cells per tank). Although the lowest values were often found in tanks that underwent ballast water exchange, the highest concentrations $\left(10^{9}\right.$ to $10^{11}$ cells per tank) were detected in all voyage categories: transoceanic with ballast exchange (TOE), and intra-coastal with exchange (ICE) and without exchange (ICU). For the west coast, $36 \%$ of tanks carried detectable quantities of diatoms and there was no statistical difference between ship categories. For the east coast, $60 \%$ of tanks contained diatoms; ICU represented a bioinvasion pattern based on more frequent events with consistently lower cell concentrations, whereas ICE and TOE corresponded to less frequent events, though more variable in cell concentrations. Diversity reached 40 taxa per tank, including resting stages and cells that were supposedly growing vegetatively. New records may lead to introduction hypotheses that ought not to be accepted uncritically. Cell viability was tested using the vital stain fluorescein diacetate; parallel counts of protoplasm integrity and chlorophyll autofluorescence revealed that all 3 indicators gave results within the same order of magnitude. Inoculation of 0.2 to $0.5 \mathrm{ml}$ of the slurry into culture media led to the growth of diatoms, even of taxa not initially detected. Within $7 \mathrm{~d}$, cultured assemblages reached cell concentrations equivalent to 1.8 to 4.4 doublings of the original inoculation.
\end{abstract}

KEY WORDS: Diatoms $\cdot$ Biological invasion $\cdot$ Ballast sediment $\cdot$ Propagule pressure $\cdot$ Phytoplankton viability

\section{INTRODUCTION}

Propagule pressure - that is, the number of individuals introduced and the number of introduction attempts - is a concept initially developed for organism dispersal by natural mechanisms that has provided consistent explanations for the outcomes of humanmediated bioinvasions in aquatic systems across taxa and locations (e.g. Ruiz et al. 2000, MacIsaac et al. 2001, Colautti et al. 2006). Other determinants of establishment success such as species- and habitatbased factors are also valuable but often make bioinva- sion appear idiosyncratic (Lockwood et al. 2005). The predictive strength of the propagule pressure concept has led to initiatives for the prevention and control of the introduction and dispersion of non-indigenous species (NIS) (Wonham et al. 2005, Reaser et al. 2008). It has been incorporated into the research themes of the 'Canadian Aquatic Invasive Species Network' (CAISN, www.caisn.ca) and is playing a central role in demonstrating shipping to be the most important vector supply of NIS to and between marine and freshwater systems in North America (Ruiz et al. 2000, Ricciardi 2001). 
A wide range of organisms are transported in ship ballast tanks (e.g. Medcof 1975, Carlton 1985, Carlton \& Geller 1993, Galil \& Hülsmann 1997, Drake et al. 2007) and, among the microalgae, diatoms and dinoflagellates are well represented in abundance and diversity (e.g. Hallegraeff \& Bolch 1992, Marangoni et al. 2001, Forbes \& Hallegraeff 2002, Burkholder et al. 2007, Klein et al. 2009a,b). Dinoflagellates have been a frequent target of more in-depth investigation (Hallegraeff \& Bolch 1992, Rigby \& Hallegraeff 1994, Hamer et al. 2000, 2001, Pertola et al. 2006). This is mostly due to a valid perception of the survival advantage of cyst-forming species under the adverse conditions found in ballast tanks, as well as being a repercussion of case studies of toxin-producing species known to impact fisheries and aquaculture, whose bioinvasion histories have been charted based on paleontological records and/or molecular evidence (McMinn et al. 1997, Scholin 1998, Doblin et al. 2004). Diatoms also figure in well-known cases of human-mediated introductions suggested by the recent appearance of a species in an extensively-surveyed area. Introduction can be inferred with confidence in the case of large and distinct species that could not have been overlooked for long had they been present in detectable quantities: e.g. Odontella sinensis (Ostenfeld 1908 cited in Hallegraeff \& Bolch 1992), Thalassiosira punctigera (Kat 1982), and Coscinodiscus wailesii, whose blooms in their introduced areas produced excess mucilage that clogged fish nets (Boalch \& Harbour 1977) and were associated with sharp decreases of phytoplankton and zooplankton populations (Fernandes et al. 2001).

Developing robust human-mediated introduction hypotheses for microalgae is, undeniably, not trivial (Smayda 2007). In addition to understanding modes and pathways of introduction, it ideally requires comprehensive historical assessments of local floras as baselines of reference, paleontological records at least for those organisms that are preserved in the sediment, and the appraisal of cryptic diversity by molecular methods. Without standardized criteria to substantiate introduction hypotheses, newly detected microalgae can be subjectively perceived and categorized as 'new records' (e.g. Martin \& LeGresley 2008), 'cryptogenics' (sensu Carlton 1996), or 'NIS'. Despite these shortcomings, the modest list of non-indigenous diatoms mentioned above illustrates the main paradigm of bioinvasion by ship ballast tanks: individuals of species need to outlive several 'filter barriers' from the donor to the receiving area (stay alive through ballast uptake, transport, deballast, and establishment); only a handful of those surviving taxa may cause ecological and/or economic distress that can be operationally detected and, hopefully, quantified (Carlton 1985). Diatoms, similar to many other microorganisms, readily multiply vegetatively under favourable conditions.
Within a ballast tank, microalgae can be found in contiguous compartments, that is, in water, sediment and biofilm (Drake et al. 2007). The assemblages in the ballast water have been most intensively examined by far, especially to investigate overall survival as a function of voyage time (e.g. Kelly 1993, Olenin et al. 2000, McCarthy \& Crowder 2000) and/or the efficacy of midocean ballast water exchange as a method to minimize the translocation of NIS (e.g. Rigby \& Hallegraeff 1994, Zhang \& Dickman 1999, Villac et al. 2001, McCollin et al. 2007, Taylor et al. 2007, Klein et al. 2009a,b). The few studies that included ballast sediments confirmed the occurrence and/or germinating potential of dinoflagellate cysts and/or diatoms (Hallegraeff \& Bolch 1992, Kelly 1993, Rigby \& Hallegraeff 1994, Hamer et al. 2000, 2001, Villac et al. 2001, Waters et al. 2001, Pertola et al. 2006). The ability of diatoms to survive the adverse conditions of ballast tanks (darkness, anoxia, fluctuating salinity, temperature and nutrient availability) does not come as a surprise. Formation of resting spores or resting cells (the first with morphological differentiation from vegetative forms) is a known survival strategy for diatoms (reviewed in McQuoid \& Hobson 1996), among other physiological competences such as enzyme production for energy storage and the uptake of reduced carbon (discussed in Klein et al. 2009b).

Estimating the composition and abundance of viable diatoms in ballast sediments has conceptual and methodological implications. For the sake of simplicity, let's consider that a 'live cell' equates to a 'viable cell'. In reality, the expression of viability (as in the ability to multiply, for example) can vary with environmental conditions and the physiological basis of phytoplankton cell death is not fully understood (Franklin et al. 2006). Evidence shows that automortality (or natural cell death) takes place in successive stages: (1) compromised cell membranes, (2) degradation of photosynthetic pigments, and (3) fragmentation of genomic DNA (Veldhuis et al. 2001). For logistical reasons, most quali-quantitative phytoplankton studies, either from the natural environment or from ballast tanks, are based on preserved samples. In such cases, the method used to determine which cells were alive at the time of sampling (often implying viability) is to consider those with an intact protoplasm as visualized with a transmitted light microscope or, if an epifluorescence microscope is available, the autofluorescence of the chlorophylls. In both cases, a dying cell with chloroplast(s) still fluorescing and/or with intact protoplasm may be erroneously regarded as viable. To address this drawback, several stains have been used in cell viability assays and one in particular, fluorescein diacetate (FDA), seems promising as an indicator of living phytoplankton despite cases of false negatives (Garvey et al. 2007 and references therein). Only cells with an intact 
cell membrane fluoresce green when stained with FDA; viability is thus determined before these stages of cell death take place.

The study of the sediments that accumulate on the bottom of ballast tanks presents additional challenges: (1) difficult access for direct sampling, (2) sample preparation to separate organisms from mineral particles and (3) interpretation of species composition, since the assemblages represent a composite of populations taken up in a number of ballasting operations in different bioregions and accumulated for days to months at a time. Management procedures specific for sediments are required only when cleaning or repair of ballast tanks occurs, in which case reception facilities should be available for the final disposal of sediments (IMO 2004). During routine operations, however, present voluntary and mandatory ship ballast management options are mostly centered on reducing the load of NIS discharged in ballast waters through mid-ocean exchange and/or water treatment on-board (Gollasch et al. 2007). Although it is fair to assume that organisms in the re-suspended sediment are also killed by onboard ballast water treatment, large quantities of residual biota and sediment accumulate on the bottom of the tanks and remain unpumpable (e.g. Hallegraeff \& Bolch 1992, Galil \& Hülsmann 1997, Villac et al. 2001, Bailey et al. 2007). The risk of introducing NIS that accumulate in the sediments was demonstrated by increasing bioinvasion events in the Laurentian Great Lakes associated with no-ballast-on-board (NOBOB) ships (Ricciardi 2001). Until 2006, NOBOB ships were not required to carry out any type of ballast management before entering the area and, once in the system, were allowed to perform routine ballast/deballast procedures (Transport Canada 2006) in those presumed safe tanks in which, in fact, organisms in the sediment were resuspended and discharged (Bailey et al. 2007).

The present study is part of the CAISN program and, therefore, our access to ballast sediment samples from commercial ships was greatly facilitated. Consistent with the terminology adopted by CAISN which, in turn, reflects the various 'filter barriers' of bioinvasion mentioned above, our short-term objectives were (1) to assess the actual propagule pressure of diatoms present in the sediment of ballast tanks upon arrival at Canadian ports (or 'how much and what arrives alive?'); and (2) to assess the effective propagule pressure of diatoms present in the sediment of ballast tanks after incubation and cell growth under controlled laboratory conditions (or 'what and how much grows after arrival?'). This study presents quantitative diatom data from sediments collected in ballast tanks (largely lacking in published records) that can be incorporated into our developing understanding of patterns of bioinvasion by microorganisms mediated by shipping.

\section{MATERIALS AND METHODS}

Collection and screening of samples. A total of 118 samples were taken during 2007 and 2008 from ships that came to Canadian ports on the west coast (WC, 70 samples) and the east coast (EC, 48 samples). Sampling was carried out in one tank per ship, after water deballast. The sediment was manually collected from different parts of the tank, homogenized in a bucket, and ca. $200 \mathrm{ml}$ was preserved with $20 \mathrm{ml}$ Lugol's solution, and stored refrigerated in the dark until analysis. Two smears per sample of this sediment were examined using light microscopy. Those samples with at least one diatom cell with normal, intact protoplasm were selected for detailed microscopic study. Samples with frustules packed with dark-brown amorphous content were also selected; such dead cells were used as indicators of the potential presence of live ones. In addition, 12 live samples (not preserved with Lugol's solution) were taken in the same manner from ships that came to the EC in 2009, stored refrigerated in the dark, immediately shipped to the laboratory, and processed 3 to $4 \mathrm{~d}$ after collection. A total of 130 samples (both preserved and live) were inspected, 66 of them in detail (28 WC, 38 EC; Tables 1 \& 2).

Retrieving diatoms from the sediment. Retrieval was based on density gradient separation by centrifugation, modified for diatoms from methods proposed to recover live dinoflagellate cysts by Blanco (1986) and Bolch (1997). The former used the colloidal silica solution Ludox whereas the latter used sodium polytungstate (SPT). Optimization took into account the specific density of diatoms which is similar to that of silica-rich minerals in the diatom frustule, since preserved cells no longer have buoyancy mechanisms in place. Both solutions can be used with preserved samples treated with milli-Q water without disrupting the cells; only SPT was used with live samples because Ludox may be toxic to some organisms and tends to react with seawater to form a thicker gel (de Jonge 1979). Preliminary tests indicated the use of Ludox TM-50 at density of $1.4 \mathrm{~g} \mathrm{ml}^{-1}$ for lighter sediments, up to $1.41 \mathrm{~g}$ wet weight (ww), and SPT at density $2.2 \mathrm{~g} \mathrm{ml}^{-1}$ for heavier sediments (data not shown). The step-by-step procedure followed more closely that described by Bolch (1997), starting with $1 \mathrm{ml}$ of sediment, applying the gradient technique to the 10$100 \mu \mathrm{m}$ fraction, and saving both retrieved diatoms and pelleted sediment for analysis. Two subsamples taken from an untreated sample could be processed in ca. $1 \mathrm{~h}$. The 10 to $100 \mu \mathrm{m}$ fraction was selected because the upper limit excluded large mineral particles, but still allowed the passage of most diatoms; the lower limit is in accordance with international standards for ballast water management (regulation D-2, IMO 2004) that 
permits deballasting of given numbers of organisms by size classes, with $\geq 10 \mu \mathrm{m}$ being the lowest limit except for bacteria of concern for human health.

Microscopic evaluation of preserved samples. The Utermöhl technique (Hasle 1978) was used for cell counts and initial identification. Only cells of ca. $5 \mu \mathrm{m}$ and larger, with intact protoplasm and distinct chloroplasts, were taken into account $(400 \times$ final magnification). A minimum of 300 cells were counted to achieve a $95 \%$ probability of finding a species that comprised $1 \%$ of the population (Shaw 1964); for samples that did not reach this threshold, at least half of the Utermöhl chamber was inspected. Light microscopy counts were done in duplicate, that is, 2 subsamples were independently processed by gradient centrifugation and average numbers are reported. Preliminary tests indicated that increasing the number of subsamples up to 4 did not consistently reduce the error estimated with 2 subsamples (data not shown). The sediment pellets were inspected with Sedgewick-Rafter chambers and an upright light microscope to further assess the efficiency and reproducibility of the gradient centrifugation method. Total propagule number was the sum of cells found in both fractions. Detailed taxonomic analysis was done with scanning electron microscopy using a JEOL JSM-5600 operating at $10 \mathrm{kV}$ and $8 \mathrm{~mm}$ working distance, for which preparations followed the method described in Kaczmarska et al. (2005).

Live cell counting techniques. Six of the 12 live samples (EC-105 to EC-110) were processed by gradient centrifugation to retrieve diatoms using SPT and sterile filtered seawater (3 to 4 preparations per sample). Detection of viable cells using the FDA stain was done according to Garvey et al. (2007) with a few modifications. Subsamples $(2 \mathrm{ml})$ of each preparation were incubated with FDA $\left(2.0 \mu \mathrm{g} \mathrm{ml}^{-1}\right.$, final concentration) for 10 to $20 \mathrm{~min}$ in cool dark conditions. FDA-stained cells were counted by epifluorescence with a filter set that allowed for the excitation and emission of the stain while blocking interfering emissions from chlorophylls (Zeiss set 10: excitation 450-490 nm, beam splitter $510 \mathrm{~nm}$, emission 515-565 nm). Sedgewick-Rafter chambers were used under $200 \times$ final magnification; $25 \%$ of the chamber was inspected. Only cells that could be recognized as unambiguously fluorescing bright green were counted. Each count lasted ca. 60 to a maximum of 90 min due to constraints determined by the stain. The goal was to reach at least 100 cells; in practice, some counts reached only ca. 40 cells (due to sparsity of live diatoms); thus the need to count and average 2 subsamples for such preparations. Aliquots of the same preparations were preserved with glutaraldehyde (2.5\% final concentration) for additional, independent enumeration of cells showing autofluorescence of the chlorophylls (Zeiss set 9: excitation
450-490 nm, beam splitter $510 \mathrm{~nm}$, emission $515 \mathrm{~nm}$ ) and protoplasm integrity (transmitted light) with the same counting effort ( $25 \%$ of the chamber). These additional counts were performed after 20 to $30 \mathrm{~d}$ so as to simulate the common circumstances when ballast samples are not readily available for processing in the laboratory.

Growth experiment. For another set of 4 live samples (EC-113 to EC-116), 4 subsamples of $1 \mathrm{ml}$ each were rinsed with sterile filtered seawater through a $100 \mu \mathrm{m}$ sieve. The material was retrieved onto a $10 \mu \mathrm{m}$ sieve and re-suspended in a test tube with $20 \mathrm{ml}$ of sterile filtered seawater. The resulting slurry was used for cell counts performed with FDA as described above, which was possible because the signal was strong enough, despite the amount of detritus in the background. The one FDA-subsample with the cell count closest to the average cell concentration for that sample was chosen for a growth experiment. A known volume $(0.2$ to $0.5 \mathrm{ml})$ was inoculated into $3 \mathrm{ml}$ of culture media (Guillard f/2, salinity $26 \mathrm{psu}$ ) in a 12-well tissue plate and incubated for $7 \mathrm{~d}\left(20 \pm 1^{\circ} \mathrm{C}\right.$, ca. $36 \mu \mathrm{mol}$ photons $\mathrm{m}^{-1} \mathrm{~s}^{-1}$ ). Each sample was inoculated into 6 wells; 3 of them were counted on Day 1 and the other 3 on the Day 7. Growth was calculated as doubling times from $\mathrm{K}=\log \left(N_{\text {Day }} / N_{\text {Day } 0}\right)(3.322 / t)$, where $N$ is the average cell count and $t$ is the growth period in days (Guillard 1973). In addition, this same growth experiment was done with the live material from EC-105 to EC-110, although the starting point was 1 sieved subsample that did not necessarily represent the average cell count of the sample. Attempts to grow diatoms from the samples previously processed with SPT were unsuccessful (zero growth) despite the chemical having being shown to be non-harmful to dinoflagellate cysts (Bolch 1997).

Statistical analysis. In our statistical inferences, the 'reduced data set' refers only to samples in which live diatoms were detected, whereas 'complete data set' refers to all samples analyzed starting with the initial screening by the smear preparation, including those in which possible live diatoms were below our detection level (thus considered equivalent to zero live diatoms found). Ships that reached the WC and EC ports were divided into 3 categories: transoceanic with ballast exchanged (TOE), intra-coastal with ballast exchanged (ICE), and intra-coastal with unexchanged ballast (ICU). Possible differences across ship categories (at $95 \%$ confidence) were tested by 1-way ANOVA with an additional Welch test to account for unequal sample size. Data were transformed using $\log (x+10)$ to achieve normal distribution. When the null hypothesis of equal means was rejected, a Bonferroni post-hoc test was performed to further detail a pattern; when assumptions of ANOVA were invalid or suspect, the 
nonparametric median test for $k$-independent samples (PASW ${ }^{\circledR}$ Statistics18) was applied. The pairwise comparison between indicators of cell viability (FDA, autofluorescence and protoplasm) was performed using the non-parametric Mann-Whitney $U$-test.

Methodological insights regarding the reproducibility of results, detection level, effectiveness of prescreening with smears, the recovery efficiency of diatoms by gradient density centrifugation, and potential impediments in the successful use of STP (the solution for gradient density) and FDA (the vital stain) are available in the supplement at www-int-res.com/ articles/supp/m425p047_supp.pdf.

\section{RESULTS}

\section{Propagule numbers and species composition}

Of the 54 preserved samples selected for detailed analysis, only 5 did not have any cells with intact protoplasm (Tables $1 \& 2$ ). In the remaining of the samples, preserved and not preserved, the concentration of live diatoms varied from 56 to $4.6 \times 10^{5}$ cells $^{-1}$ ww $\left(\right.$ mean $\pm \mathrm{SD} 2 \times 10^{4} \pm 7 \times 10^{4}$ cells g $\left.{ }^{-1} \mathrm{ww}\right) ; 16 \%$ of them were above average and $51 \%$ in the $10^{3}$ range (Tables 1 \& 2, Fig. 1). When extrapolated to the whole

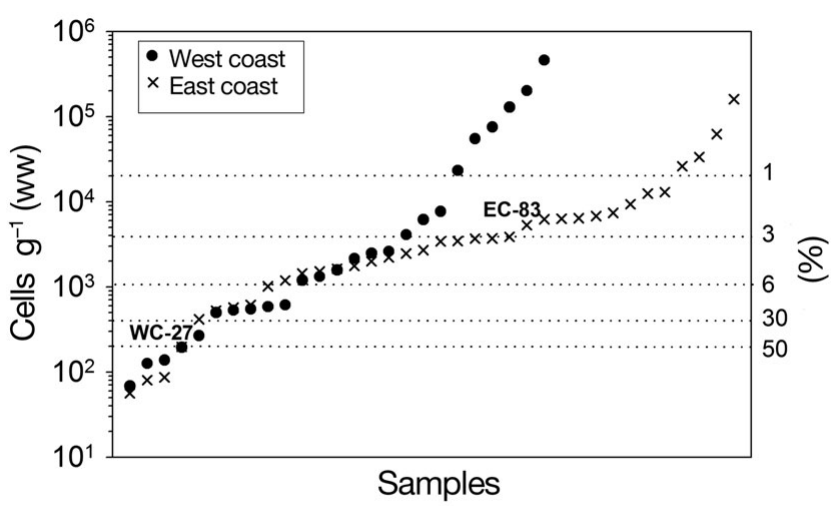

Fig. 1. Distribution of cell concentration $\left(\mathrm{g}^{-1}\right.$ wet weight, ww) for Canadian west and east coasts (only the 61 samples in which diatoms were detected are included in the analysis). Dotted lines indicate detection levels (\%) of the taxa in a sample, as determined in Shaw (1964). For example: samples on and above the top line were those in which a minimum of 300 cells were directly visualized and counted to achieve a 95\% probability of finding a species that comprised $1 \%$ of the population (as indicated on the right side of the figure). The subsequent lines correspond to samples with lower cell counts and their respective detection levels $(3 \%, 6 \%, 30 \%$ and $50 \%)$ at the same $95 \%$ probability of occurrence. See 'Results: Propagule numbers and species composition' for comments about the samples noted as WC-27 and EC-83 in comparison to their position on Fig. 2

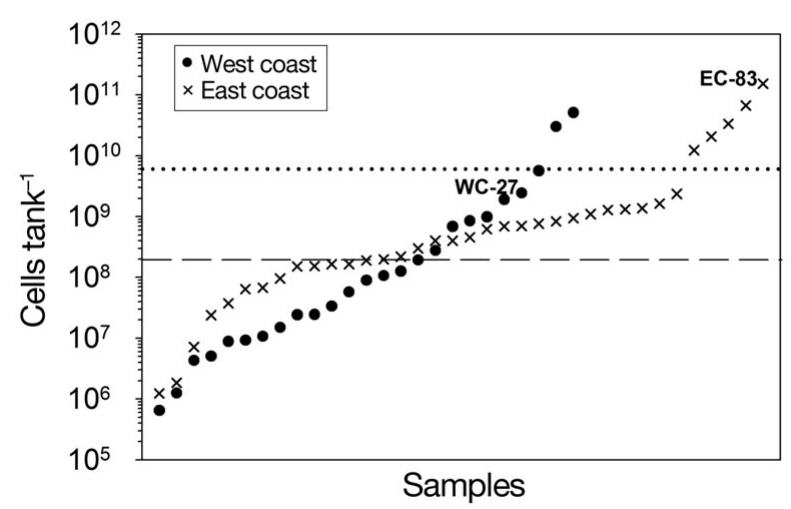

Fig. 2. Distribution of cell concentration (per tank) for Canadian west and east coasts (only the 61 samples in which diatoms were detected are included in the analysis). Dotted line indicates the overall average value and dashed line the median. See 'Results: Propagule numbers and species composition' for comments about the samples noted as WC-27 and EC-83 in comparison to their position on Fig. 1

amount of sediment estimated for each tank, diatom cell concentration varied from $6 \times 10^{5}$ to $1.5 \times 10^{11}$ cells per tank (average: $6 \times 10^{9} \pm 2 \times 10^{10}$ cells per tank); $11 \%$ of these samples were above average and $59 \%$ in the $10^{7}$ to $10^{8}$ range (Tables $1 \& 2$, Fig. 2). Calculations of the amount of sediment per tank was based on direct observations of sediment depth and percent cover inside ballast tanks, combined with their respective architectural diagrams (provided by and according to Briski et al. 2010). The ranking of certain ships changed when data were transformed from cells $\mathrm{g}^{-1} \mathrm{ww}$ to cells per tank (compare Figs. 1 \& 2). For example, both WC-27 (Table 1) and EC-83 (Table 2) had relatively lower concentrations in terms of cells $\mathrm{g}^{-1} \mathrm{Ww}$ and higher concentrations in terms of cells per tank. A further extrapolation to cells per ship based on total number and volume of tanks in a given ship indicated EC-83 as transporting the highest diatom concentrations of all ships investigated $\left(1.6 \times 10^{12}\right.$ cells; Table 2$)$. In the results and discussions that follow, we will consider cells per tank as a more accurate estimate of propagule pressure, since inter-tank variability has been demonstrated for dinoflagellates in the sediments (Hamer et al. 2000) and phytoplankton in the water (Burkholder et al. 2007).

The detailed taxonomy of some taxa grouped at the genus or family level (see Table 4) is in progress so that the assessment of species richness is currently underestimated. The number of taxa per tank varied from 1 to 40 (average of $14 \pm 10$ taxa). Of the 28 samples that had concentrations $\geq 2 \times 10^{8}$ cells per tank (the median value), $33 \%$ had over 20 taxa per tank (Fig. 3). ICE ships that came to both WC and EC stood out as having lower average number of taxa (respectively, $9 \pm$ 
Table 1. Sediment samples collected in ballast tanks of ships that reached the port of Vancouver on the Canadian west coast (WC) and selected for detailed microscopic analysis (see 'Materials and methods: Collection and screening of samples'). Ship categories are transoceanic with ballast exchange (TOE), intra-coastal with ballast exchange (ICE), and intra-coastal with unexchanged ballast (ICU). Cell concentrations are based on protoplasm integrity. Amounts of sediment per tank and sediment per ship provided by E. Briski (estimated as in Briski et al. 2010). ww: wet weight

\begin{tabular}{|c|c|c|c|c|c|c|c|c|}
\hline $\begin{array}{l}\text { Sample } \\
\text { code }\end{array}$ & $\begin{array}{l}\text { Sampling } \\
\text { date }\end{array}$ & $\begin{array}{l}\text { Last port before } \\
\text { reaching Canada }\end{array}$ & $\begin{array}{l}\text { Cells g }^{-1} \\
(w w)\end{array}$ & $\begin{array}{l}\text { Cells per } \\
\text { tank }\end{array}$ & $\begin{array}{l}\text { Cells per } \\
\text { ship }\end{array}$ & $\begin{array}{l}\text { No. of } \\
\text { taxa }\end{array}$ & $\begin{array}{l}\text { Ship } \\
\text { category }\end{array}$ & $\begin{array}{l}\text { Ship } \\
\text { cargo }\end{array}$ \\
\hline WC-06 & 8 Jun 07 & Zhangjiagang, China & 1571 & $2.5 \mathrm{E}+07$ & $2.5 \mathrm{E}+08$ & 15 & TOE & Bulk carrier \\
\hline WC-07 & 10 Jun 07 & Los Angeles, CA, USA & 2143 & $5.0 \mathrm{E}+06$ & $1.1 \mathrm{E}+08$ & 21 & ICE & Bulk carrier \\
\hline WC-12 & 19 Jun 07 & Long Beach, CA, USA & 138 & $1.1 \mathrm{E}+07$ & $1.6 \mathrm{E}+08$ & 1 & ICE & Bulk carrier \\
\hline $\mathrm{WC}-17^{\mathrm{a}}$ & 9 Jul 07 & Portland, OR, USA + Kobe, Japan & an 531 & $1.2 \mathrm{E}+06$ & $2.7 \mathrm{E}+07$ & 7 & ICE+TOE & General cargo \\
\hline WC-18 & 10 Aug 07 & Portland, OR, USA & 126 & $9.2 \mathrm{E}+06$ & $1.5 \mathrm{E}+08$ & 6 & TOE & Bulk carrier \\
\hline WC-24 & 14 Nov 07 & Long Beach, CA, USA & 457103 & $9.8 \mathrm{E}+08$ & $2.4 \mathrm{E}+10$ & 12 & ICE & Bulk carrier \\
\hline WC-27 & 22 Feb 08 & Rizhao, China & 549 & $2.4 \mathrm{E}+09$ & $2.1 \mathrm{E}+10$ & 8 & TOE & unknown \\
\hline WC-30 & 28 Mar 08 & Kinuura, Japan & 128474 & $2.8 \mathrm{E}+08$ & $4.9 \mathrm{E}+09$ & 35 & TOE & unknown \\
\hline WC-33 & 3 Apr 08 & Cao Fei Dian, China & 75131 & $3.0 \mathrm{E}+10$ & $3.2 E+11$ & 19 & TOE & Bulk carrier \\
\hline WC-35 & 4 Apr 08 & Lanshan, China & 68 & $2.4 \mathrm{E}+07$ & $5.6 \mathrm{E}+08$ & 3 & TOE & unknown \\
\hline WC-36 & 8 Apr 08 & Ofunato, Japan & 1313 & $1.9 \mathrm{E}+08$ & $6.4 \mathrm{E}+09$ & 19 & TOE & Bulk carrier \\
\hline WC-38 & 16 Apr 08 & Qingdao, China & 23174 & $5.6 \mathrm{E}+09$ & $6.0 \mathrm{E}+10$ & 15 & TOE & Bulk carrier \\
\hline WC-39 & 29 Apr 08 & Portland, OR, USA & 267 & $4.3 \mathrm{E}+06$ & $6.1 \mathrm{E}+07$ & 6 & ICU & Bulk carrier \\
\hline WC-40 & 6 May 08 & Portland, OR, USA & 497 & $1.5 \mathrm{E}+07$ & $1.6 \mathrm{E}+08$ & 16 & ICU & Bulk carrier \\
\hline WC-43 & 4 Jun 08 & Seattle, WA, USA & 7647 & $1.1 \mathrm{E}+08$ & $2.5 \mathrm{E}+09$ & 28 & ICU & unknown \\
\hline WC-44 & $11 \mathrm{Jul} 08$ & Ferndale, WA, USA & 611 & $8.8 \mathrm{E}+06$ & $6.1 \mathrm{E}+07$ & 8 & ICE & Bulk carrier \\
\hline WC-46 & $15 \mathrm{Jul} 08$ & Manzanillo, Mexico & 583 & $6.5 \mathrm{E}+05$ & $1.7 \mathrm{E}+07$ & 19 & ICE & Bulk carrier \\
\hline WC-48 & 24 Jul 08 & Nantong, China & 4092 & $1.3 \mathrm{E}+08$ & $3.4 \mathrm{E}+09$ & 24 & TOE & Bulk carrier \\
\hline WC-51 & 7 Aug 08 & Portland, OR, USA & 54735 & $5.8 \mathrm{E}+07$ & $1.1 \mathrm{E}+09$ & 14 & ICU & General cargo \\
\hline WC-53 & 23 Aug 08 & Longview, WA, USA & 2474 & $3.3 \mathrm{E}+07$ & $8.7 \mathrm{E}+08$ & 20 & ICU & General cargo \\
\hline WC-54 & 25 Aug 08 & Seattle, WA, USA & 201583 & $5.1 \mathrm{E}+10$ & $1.3 \mathrm{E}+12$ & 37 & ICU & Container \\
\hline WC-58 & 5 Sep 08 & Anacortes, WA, USA & 6144 & $9.0 \mathrm{E}+07$ & $1.1 \mathrm{E}+09$ & 14 & ICE & General cargo \\
\hline WC-59 & 11 Sep 08 & Los Angeles, CA, USA & 0 & 0 & 0 & 0 & ICE & Bulk carrier \\
\hline WC-61 & 22 Sep 08 & Los Angeles, CA, USA & 0 & 0 & 0 & 0 & ICE & MPC vessel \\
\hline WC-62 & 24 Sep 08 & Vancouver, WA, USA & 195 & $8.5 \mathrm{E}+08$ & $1.2 \mathrm{E}+10$ & 5 & ICU & General cargo \\
\hline WC-64 & 6 Oct 08 & Los Angeles, CA, USA & 0 & 0 & 0 & 0 & ICE & Bulk carrier \\
\hline WC-65 & 8 Oct 08 & Los Angeles, CA, USA & 1189 & $1.9 \mathrm{E}+09$ & $2.7 \mathrm{E}+10$ & 15 & ICE & unknown \\
\hline WC-66 & 15 Oct 08 & Ferndale, WA, USA & 2610 & $6.8 \mathrm{E}+08$ & $1.0 \mathrm{E}+10$ & 24 & ICU & Bulk carrier \\
\hline \multicolumn{3}{|c|}{ Minimum } & 0 & 0 & 0 & 0 & & \\
\hline \multicolumn{3}{|c|}{ Maximum } & 457103 & $5.1 \mathrm{E}+10$ & $1.3 \mathrm{E}+12$ & 37 & & \\
\hline \multicolumn{3}{|c|}{ Median } & 1251 & $4.6 \mathrm{E}+07$ & $9.9 \mathrm{E}+08$ & 15 & & \\
\hline \multicolumn{3}{|l|}{ Mean } & 34748 & $3.4 \mathrm{E}+09$ & $6.3 E+10$ & 14 & & \\
\hline \multicolumn{3}{|l|}{$\mathrm{SD}$} & 94593 & $1.1 \mathrm{E}+10$ & $2.4 \mathrm{E}+11$ & 10 & & \\
\hline
\end{tabular}

9 and $11 \pm 10$ taxa) than ICU ships (respectively, $17 \pm$ 11 and $24 \pm 11$ ). For TOE ships, species richness in EC samples was lower $(11 \pm 10$ taxa) than in WC samples $(16 \pm 10$ taxa $)$.

\section{Actual and effective propagule pressure}

For the WC, depending on the type of ship (ICU, ICE, TOE), 32 to $43 \%$ of the samples carried diatoms at cell concentrations detectable by our methods (Table 3). Average diatom cell concentrations were lower in the ICE ships $\left(4.3 \times 10^{8}\right.$ cells per tank), followed by the TOE ships $\left(4.3 \times 10^{9}\right.$ cells per tank $)$ and ICU ships $(5.8 \times$ $10^{9}$ cells per tank), although these differences were not statistically significant (Table 3, Fig. 4a).
For the EC, diatoms were found in 41 to $100 \%$ of the samples, that is, in all 17 tanks of ICU ships, but only in 9 samples from 22 TOE ships and in 10 of 21 samples from ICE ships (Table 3). In contrast to the WC, propagule pressure to the EC had different statistical interferences depending on whether the complete data set or the reduced data set were analyzed (Table 3, Fig. 4b). When all samples were considered ( $\mathrm{n}=60$ ), ICU ships significantly differed from ICE and TOE ships: the first had consistently lower average cell concentrations $\left(6 \times 10^{8}\right.$ cells per tank, smaller standard error) whereas the other 2 had more variable and higher average cell concentrations (respectively, $9 \times 10^{9}$ and $5 \times 10^{9}$ cells per tank, larger standard errors). Once a tank was recognized as carrying diatoms $(n=36)$, there was no significant 
difference in propagule pressure across ship types (Fig. 4b).

The comparison between indicators of cell viability was done with a subset of the live samples (EC-105 to
EC-110; Table 2) that had relatively low cell concentrations (ca. $10^{3}$ cells $\mathrm{g}^{-1} \mathrm{ww}$ ) and thus large variations between preparations of a given sample; nevertheless, trends were consistent (Fig. 5). As expected, cell con-

Table 2. Sediment samples collected in ballast tanks of ships that reached different ports on the Canadian east coast (EC) and selected for detailed microscopic analysis (see 'Materials and methods: Collection and screening of samples'). Ship categories are transoceanic with ballast exchange (TOE), intra-coastal with ballast exchange (ICE), and intra-coastal with unexchanged ballast (ICU). Cell concentrations are based on protoplasm integrity, unless otherwise noted. Amount of sediment per tank and sediment per ship provided by E. Briski (estimated as in Briski et al. 2010). ww: wet weight

\begin{tabular}{|c|c|c|c|c|c|c|c|c|c|}
\hline $\begin{array}{l}\text { Sample } \\
\text { code }\end{array}$ & $\begin{array}{l}\text { Sampling } \\
\text { date }\end{array}$ & $\begin{array}{l}\text { Last port before } \\
\text { reaching Canada }\end{array}$ & $\begin{array}{l}\text { Arrival } \\
\text { port }\end{array}$ & $\begin{array}{l}\text { Cells g }^{-1} \\
\text { (ww) }\end{array}$ & $\begin{array}{c}\text { Cells } \\
\text { per tank }\end{array}$ & $\begin{array}{l}\text { Cells } \\
\text { per ship }\end{array}$ & $\begin{array}{l}\text { No. of } \\
\text { taxa }\end{array}$ & $\begin{array}{l}\text { Ship } \\
\text { category }\end{array}$ & $\begin{array}{l}\text { Ship } \\
\text { cargo }\end{array}$ \\
\hline \multicolumn{10}{|c|}{ Preserved samples } \\
\hline EC-01 & 27 Apr 07 & Liverpool, UK & Sept-Iles, QC & 1439 & $2.0 \mathrm{E}+08$ & $4.5 \mathrm{E}+09$ & 7 & TOE & General cargo \\
\hline EC-03 & 29 Apr 07 & New Orleans, LA, USA & Baie-Comeau, QC & C 1017 & $1.8 \mathrm{E}+06$ & $5.9 \mathrm{E}+07$ & 16 & ICE & Bulk carrier \\
\hline EC-07 & 1 May 07 & Port Bury, UK & Sept-Iles, QC & 33664 & $6.4 \mathrm{E}+07$ & $9.4 \mathrm{E}+08$ & 24 & TOE & Bulk carrier \\
\hline $\mathrm{EC}-12$ & 5 May 07 & Baltimore, PA, USA & Sept-Iles, QC & 86 & $1.2 \mathrm{E}+06$ & $1.7 \mathrm{E}+07$ & 2 & ICE & Bulk carrier \\
\hline $\mathrm{EC}-14$ & 7 May 07 & Gijon, Spain & Sept-Iles, QC & 62144 & $4.0 \mathrm{E}+08$ & $5.6 \mathrm{E}+09$ & 21 & TOE & Bulk carrier \\
\hline $\mathrm{EC}-17$ & 9 May 07 & Eddystone, PA, USA & Sept-Iles, QC & 9336 & $1.1 \mathrm{E}+09$ & $1.4 \mathrm{E}+10$ & 33 & ICE & Bulk carrier \\
\hline EC-19 & 23 May 07 & Zelzate, Belgium & Sept-Iles, QC & 571 & $1.5 \mathrm{E}+08$ & $2.8 \mathrm{E}+09$ & 6 & TOE & General cargo \\
\hline $\mathrm{EC}-21$ & 24 May 07 & Rotterdam, Netherlands & Sept-Iles, QC & 0 & 0 & 0 & 0 & TOE & Bulk carrier \\
\hline $\mathrm{EC}-22$ & 24 May 07 & Trombetas, Brazil & Port-Cartier, QC & 0 & 0 & 0 & 0 & TOE & Bulk carrier \\
\hline EC-37 & 19 Jun 07 & Zelzate, Belgium & Sept-Iles, QC & 26106 & $1.2 \mathrm{E}+10$ & $3.2 \mathrm{E}+11$ & 33 & TOE & Bulk carrier \\
\hline EC-45 & 23 Jun 07 & Ghent, Belgium & Sept-Iles, QC & 159600 & $6.7 \mathrm{E}+10$ & $8.8 \mathrm{E}+11$ & 10 & TOE & Bulk carrier \\
\hline EC-52 & 14 Aug 07 & Antwerp, Belgium & Sept-Iles, QC & 3871 & $2.1 \mathrm{E}+10$ & $3.7 \mathrm{E}+11$ & 12 & TOE & Bulk carrier \\
\hline EC-53 & 15 Aug 07 & Montoir, France & Sept-Iles, QC & 1517 & $4.6 \mathrm{E}+08$ & $7.7 \mathrm{E}+09$ & 5 & TOE & Bulk carrier \\
\hline EC-54 & 16 Aug 07 & Liverpool, UK & Sept-Iles, QC & 528 & $3.0 \mathrm{E}+08$ & $8.8 \mathrm{E}+09$ & 4 & TOE & Bulk carrier \\
\hline EC-56 & 5 Jun 08 & Ravena, NY, USA & Hantsport, NS & 2000 & $2.4 \mathrm{E}+07$ & $5.6 \mathrm{E}+08$ & 12 & ICE & Bulk carrier \\
\hline EC-59 & 7 Jun 08 & Boston, MA, USA & Saint John, NB & 7373 & $4.0 \mathrm{E}+08$ & $1.3 \mathrm{E}+10$ & 27 & ICU & Tanker \\
\hline EC-65 & 20 Jun 08 & Portland, ME, USA & Saint John, NB & 13023 & $1.4 \mathrm{E}+09$ & $2.4 \mathrm{E}+10$ & 40 & ICU & Tanker \\
\hline EC-71 & 25 Jun 08 & Philadelphia, PA, USA & Point Tupper, NS & 2695 & $3.4 \mathrm{E}+10$ & $4.3 \mathrm{E}+11$ & 13 & ICE & Tanker \\
\hline EC-75 & 28 Jun 08 & Portsmouth, VA, USA & Point Tupper, NS & 198 & $7.6 \mathrm{E}+08$ & $1.3 \mathrm{E}+10$ & 2 & ICE & Bulk carrier \\
\hline EC-78 & 2 Jul 08 & Searsport, ME, USA & Saint John, NB & 6776 & $1.6 \mathrm{E}+09$ & $2.7 \mathrm{E}+10$ & 22 & ICU & Tanker \\
\hline EC-80 & 3 Jul 08 & Boston, MA, USA & Saint John, NB & 5338 & $1.3 \mathrm{E}+09$ & $2.2 \mathrm{E}+10$ & 21 & ICU & Tanker \\
\hline EC-81 & 3 Jul 08 & Gloucester, NJ, USA & Halifax, NS & 2222 & $8.3 E+08$ & $1.5 \mathrm{E}+10$ & 11 & ICU & Tanker \\
\hline EC-83 & 7 Jul 08 & Philadelphia, PA, USA & Hawkesbury, NS & 6299 & $1.5 \mathrm{E}+11$ & $1.6 \mathrm{E}+12$ & 12 & ICE & Tanker \\
\hline EC-85 & 9 Jul 08 & Roseton, NY, USA & Halifax, NS & 415 & $9.5 \mathrm{E}+08$ & $2.3 \mathrm{E}+10$ & 6 & ICE & Bulk carrier \\
\hline EC-86 & $10 \mathrm{Jul} 08$ & New York, NY, USA & Hawkesbury, NS & 611 & $1.3 \mathrm{E}+09$ & $2.1 \mathrm{E}+10$ & 7 & ICE & Tanker \\
\hline EC-100 & 9 Aug 08 & Sparrows Point, MD, USA & Hawkesbury, NS & 80 & $3.8 \mathrm{E}+07$ & $9.8 \mathrm{E}+08$ & 2 & ICE & Bulk carrier \\
\hline \multicolumn{10}{|c|}{ Live samples } \\
\hline $\mathrm{EC}-105^{\mathrm{a}}$ & a 19 Jul 09 & Portland, ME, USA & Saint John, NB & 3700 & $6.9 \mathrm{E}+08$ & $1.1 \mathrm{E}+10$ & 10 & ICU & Tanker \\
\hline $\mathrm{EC}-106^{\mathrm{a}}$ & a 19 Jul 09 & Boston, MA, USA & Saint John, NB & 3414 & $6.2 \mathrm{E}+08$ & $1.1 \mathrm{E}+10$ & 9 & ICU & Tanker \\
\hline $\mathrm{EC}-107^{\mathrm{a}}$ & a $20 \mathrm{Jul} 09$ & Boston, MA, USA & Saint John, NB & 3676 & $7.0 \mathrm{E}+08$ & $1.2 \mathrm{E}+10$ & 7 & ICU & Tanker \\
\hline EC-108 & 20 Jul 09 & Belledune, NB, Canada & Saint John, NB & 12511 & $2.4 \mathrm{E}+09$ & $7.9 \mathrm{E}+10$ & 3 & ICU & Tanker \\
\hline $\mathrm{EC}-109^{\mathrm{a}}$ & a 21 Jul 09 & Botwood, NL, Canada & Saint John, NB & 6384 & $1.6 \mathrm{E}+08$ & $3.1 \mathrm{E}+09$ & 8 & ICU & Tanker \\
\hline $\mathrm{EC}-110^{\mathrm{a}}$ & a 21 Jul 09 & Stevensville, NL, Canada & Saint John, NB & 6212 & $6.8 \mathrm{E}+07$ & $1.1 \mathrm{E}+09$ & 12 & ICU & Tanker \\
\hline $\mathrm{EC}-111^{\mathrm{b}}$ & b $29 \mathrm{Jul} 09$ & Portland, ME, USA & Saint John, NB & 1633 & $1.9 \mathrm{E}+08$ & $3.6 \mathrm{E}+09$ & 3 & ICU & Tanker \\
\hline $\mathrm{EC}-112^{\mathrm{b}}$ & b 30 Jul 09 & Boston, MA, USA & Saint John, NB & 56 & $7.2 \mathrm{E}+06$ & $1.2 \mathrm{E}+08$ & 3 & ICU & Tanker \\
\hline $\mathrm{EC}-113^{\mathrm{b}}$ & b 30 Jul 09 & Charlottetown, PEI, Canada & Saint John, NB & 1429 & $9.6 \mathrm{E}+07$ & $3.3 \mathrm{E}+09$ & 6 & ICU & Tanker \\
\hline $\mathrm{EC}-114^{\mathrm{b}}$ & b 30 Jul 09 & St. John's, NL, Canada & Saint John, NB & 3481 & $2.2 \mathrm{E}+08$ & $7.8 \mathrm{E}+09$ & 7 & ICU & Tanker \\
\hline $\mathrm{EC}-115^{\mathrm{b}}$ & 3 Aug 09 & Boston, MA, USA & Saint John, NB & 2455 & $1.7 \mathrm{E}+08$ & $2.8 \mathrm{E}+09$ & 8 & ICU & Tanker \\
\hline $\mathrm{EC}-116^{\mathrm{b}}$ & 3 Aug 09 & Bucksport, MD, USA & Saint John, NB & 2457 & $1.5 \mathrm{E}+08$ & $2.8 \mathrm{E}+09$ & 9 & ICU & Tanker \\
\hline \multicolumn{4}{|c|}{ Minimum } & 0 & 0 & 0 & 0 & & \\
\hline \multicolumn{4}{|c|}{ Maximum } & 159600 & $1.5 \mathrm{E}+11$ & $1.6 \mathrm{E}+12$ & 40 & & \\
\hline \multicolumn{4}{|c|}{ Median } & 2576 & $4.0 \mathrm{E}+08$ & $8.3 E+09$ & 9 & & \\
\hline \multicolumn{4}{|l|}{$\begin{array}{l}\text { Mean } \\
\text { SD }\end{array}$} & 10377 & $8.0 \mathrm{E}+09$ & $1.0 \mathrm{E}+11$ & 11 & & \\
\hline \multicolumn{4}{|l|}{$\mathrm{SD}$} & 27422 & $2.7 \mathrm{E}+10$ & $3.0 \mathrm{E}+11$ & 10 & & \\
\hline
\end{tabular}




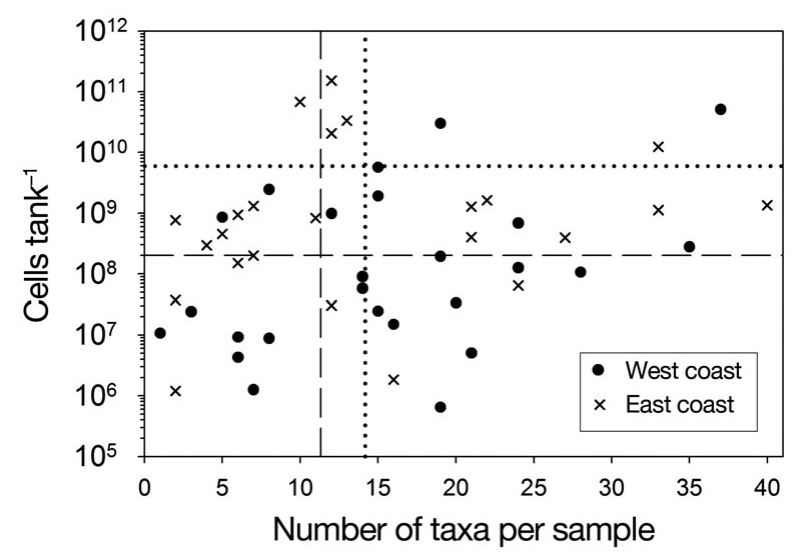

Fig. 3. Relationship between species richness and cell concentration (per tank) for Canadian west and east coasts (only the 61 samples in which diatoms were detected are included in the analysis). Dotted lines indicate overall average values and dashed lines the medians

centrations were increasingly higher from FDA fluorescence to chlorophylls autofluorescence to protoplasm integrity, though within the same order of magnitude. Based on the Mann-Whitney $U$-test applied to mean values $(\mathrm{n}=6$; Fig. 5$)$, the difference between FDA and protoplasm was marginally significant $(\mathrm{p}=$ 0.016), but the differences between FDA-autofluorescence and autofluorescence-protoplasm were not statistically significant (respectively, $\mathrm{p}=0.055$ and $\mathrm{p}=$ 0.34 ).

The inoculation of small aliquots $(0.2$ to $0.5 \mathrm{ml})$ of the original slurry into culture media led to the growth of diatoms. Within $7 \mathrm{~d}$, the total assemblage reached cell concentrations equivalent to 1.8 to 4.4 doublings of the original inoculation numbers (Fig. 6). Species that grew under our laboratory conditions are noted in Table 4 ; some of them were not detected in our initial examination (Ditylum brightwellii, Leptocylindrus danicus, Mediopyxis helysia). The detection level of the initial counts for these samples reached taxa that represented 3 to $6 \%$ of the assemblage $\left(10^{3}\right.$ cells g ${ }^{-1} \mathrm{ww}_{\text {, }}$ Fig. 1) and these species were likely present below this threshold; given favourable growth conditions, they rapidly multiplied vegetatively.

\section{DISCUSSION}

This data set, to the best of our knowledge, is the first report where (1) propagule numbers of diatoms are estimated for a large array of ballast tank sediments; (2) actual propagule pressure is assessed by the frequency and magnitude of diatom transport, differentiating ships that performed (or not) ballast water exchange en route; (3) in vitro growth rates of diatoms

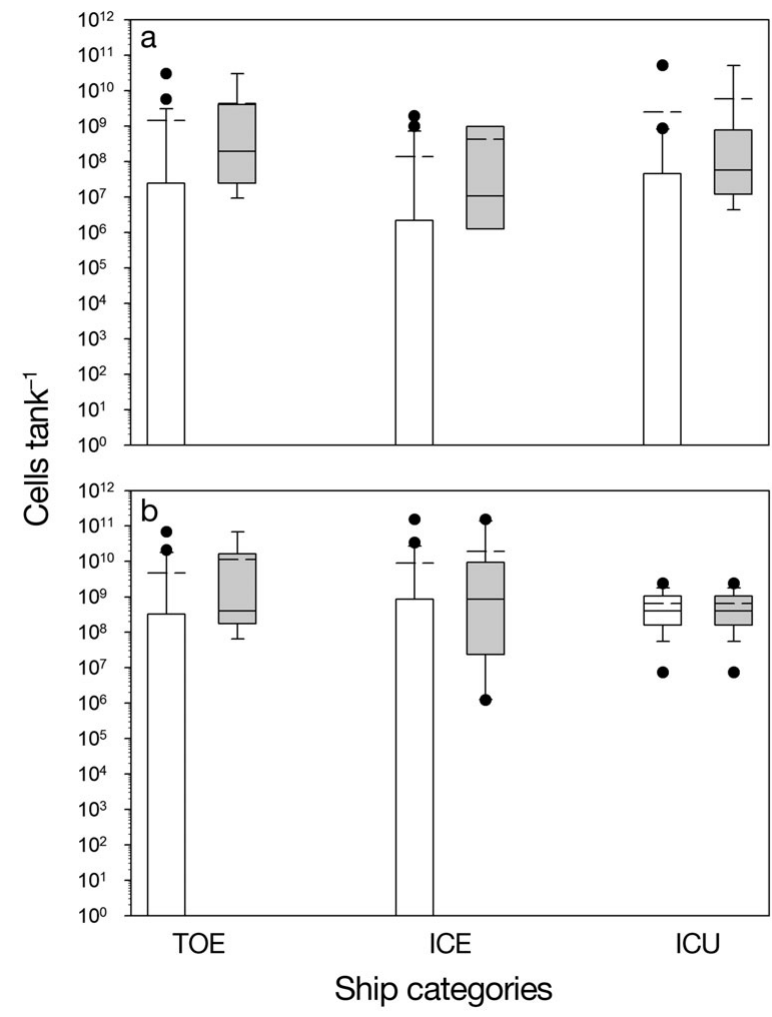

Fig 4. Average concentration of diatoms per tank found for the complete data set and the reduced data set (refer to Table $3)$, according to 3 ship types: transoceanic exchange (TOE), intra-coastal with ballast exchange (ICE), and intra-coastal with unexchanged ballast (ICU). Boxes show 25th to 75 th percentiles; error bars show 10th to 90th percentiles; solid and dashed horizontal lines are medians and means, respectively. For the west coast (a), differences are not statistically significant (1-way ANOVA and the non-parametric median test for $k$-independent samples). For the east coast (b), differences are statistically significant for the complete data set $(p=0.002$ between ICU and ICE; $p=0.001$ between ICU and TOE) but not for the reduced data set (1-way ANOVA and post-hoc Bonferroni test)

recovered from tank sediments are used to ascertain effective propagule pressure; and (4) indicators of cell viability are compared for microalgae recovered from sediment samples.

\section{Propagule numbers and species composition}

Quantitative information about microalgae in ballast sediments is largely lacking and offers maximum estimates lower than average values found in the present study: a total of $10^{2}$ diatom spores $\mathrm{ml}^{-1}$ (Villac et al. 2001); ca. $9 \times 10^{3}$ total dinoflagellate cysts $\mathrm{ml}^{-1}$ (Hamer et al. 2001); $3 \times 10^{8}$ Alexandrium tamarense cysts per tank (Hallegraeff \& Bolch 1992). Sampling efforts for dinoflagellate cysts are equivalent (Hamer et al. 2001, $n=113$ 
Table 3. Descriptive statistics of total concentration of diatom cells per tank for the samples collected in west coast (WC) and the east coast (EC) ports, according to ship categories: transoceanic with ballast exchange (TOE), intra-coastal with ballast exchange (ICE), and intra-coastal with unexchanged ballast (ICU). For each ship category, statistics are shown for the complete data set (all samples collected) and for a reduced data set (only samples with live diatoms detected). nd: live diatoms not detected

\begin{tabular}{|c|c|c|c|c|c|c|}
\hline \multirow[t]{2}{*}{ Statistic } & \multicolumn{2}{|c|}{ TOE } & \multicolumn{2}{|c|}{ ICE } & \multicolumn{2}{|c|}{ ICU } \\
\hline & Complete & Reduced & Complete & Reduced & Complete & Reduced \\
\hline \multicolumn{7}{|l|}{ West coast } \\
\hline $\mathrm{n}$ & 27 & 9 & 22 & 7 & 21 & 9 \\
\hline Minimum & nd & $9.2 \mathrm{E}+06$ & nd & $6.5 \mathrm{E}+05$ & nd & $4.3 \mathrm{E}+06$ \\
\hline Maximum & $3.0 \mathrm{E}+10$ & $3.0 \mathrm{E}+10$ & $1.9 \mathrm{E}+09$ & $1.9 \mathrm{E}+09$ & $5.1 \mathrm{E}+10$ & $5.1 \mathrm{E}+10$ \\
\hline Median & nd & $1.9 \mathrm{E}+08$ & nd & $1.1 \mathrm{E}+07$ & nd & $5.8 \mathrm{E}+07$ \\
\hline Mean & $1.4 \mathrm{E}+09$ & $4.3 E+09$ & $1.4 \mathrm{E}+08$ & $4.3 E+08$ & $2.5 \mathrm{E}+09$ & $5.8 \mathrm{E}+09$ \\
\hline $\mathrm{SD}$ & $5.8 \mathrm{E}+09$ & $9.8 \mathrm{E}+09$ & $4.5 \mathrm{E}+08$ & $7.4 \mathrm{E}+08$ & $1.1 \mathrm{E}+10$ & $1.7 \mathrm{E}+10$ \\
\hline SE of mean & $1.1 \mathrm{E}+09$ & $3.3 \mathrm{E}+09$ & $9.5 \mathrm{E}+07$ & $2.8 \mathrm{E}+08$ & $2.4 \mathrm{E}+09$ & $5.6 \mathrm{E}+09$ \\
\hline \multicolumn{7}{|l|}{ East coast } \\
\hline $\mathrm{n}$ & 22 & 9 & 21 & 10 & 17 & 17 \\
\hline Minimum & nd & $6.4 \mathrm{E}+07$ & nd & $1.2 \mathrm{E}+06$ & $7.6 \mathrm{E}+05$ & $7.6 \mathrm{E}+05$ \\
\hline Maximum & $6.8 \mathrm{E}+10$ & $6.8 E+10$ & $1.5 \mathrm{E}+11$ & $1.5 \mathrm{E}+11$ & $2.4 \mathrm{E}+09$ & $2.4 \mathrm{E}+09$ \\
\hline Median & nd & $4.0 \mathrm{E}+08$ & nd & $8.6 \mathrm{E}+08$ & $4.0 \mathrm{E}+08$ & $4.0 \mathrm{E}+08$ \\
\hline Mean & $4.7 \mathrm{E}+09$ & $1.1 \mathrm{E}+10$ & $9.1 \mathrm{E}+09$ & $1.9 \mathrm{E}+10$ & $6.0 \mathrm{E}+08$ & $6.0 \mathrm{E}+08$ \\
\hline $\mathrm{SD}$ & $1.5 \mathrm{E}+10$ & $2.2 \mathrm{E}+10$ & $3.4 \mathrm{E}+10$ & $4.8 \mathrm{E}+10$ & $7.0 \mathrm{E}+08$ & $7.0 \mathrm{E}+08$ \\
\hline SE of mean & $3.2 \mathrm{E}+09$ & $7.5 \mathrm{E}+09$ & $7.3 \mathrm{E}+09$ & $1.5 \mathrm{E}+10$ & $1.7 \mathrm{E}+08$ & $1.7 \mathrm{E}+08$ \\
\hline
\end{tabular}

Table 4. Diatoms found in the sediments of ballast tanks, those that stood out for their frequency, for being potentially harmful and/or new to the area, and those that grew in the incubation experiments, representing ca. $40 \%$ of taxa identified to date. WC: west coast; EC: east coast; fr: first record; gr: grown in experiment; tx: toxin producer

\begin{tabular}{|c|c|c|c|}
\hline Taxon & Notes & Taxon & Notes \\
\hline Actinocyclus spp. & WC, EC, gr & Paralia sulcata & $\mathrm{WC}, \mathrm{EC}, \mathrm{gr}$ \\
\hline Actinoptychus senarius & $\mathrm{WC}, \mathrm{EC}, \mathrm{gr}$ & Plagiogrammopsis vanheurckii & $\mathrm{WC}, \mathrm{EC}$ \\
\hline Asterionella formosa & WC-fr, EC & Pleurosigma/Gyrosigma spp. & WC, EC, gr \\
\hline Asterionellopsis glacialis & WC-fr, EC, gr & Pseudo-nitzschia multiseries & $\mathrm{WC}, \mathrm{tx}$ \\
\hline Asteromphalus hyalinus & WC-fr & Pseudo-nitzschia pungens & $\mathrm{WC}, \mathrm{tx}$ \\
\hline Aulacoseira ambigua & WC-fr, EC & Pseudo-nitzschia turgidula & EC-fr, tx \\
\hline Aulacoseira granulata & WC, EC & Skeletonema spp. & $\mathrm{WC}, \mathrm{EC}, \mathrm{gr}$ \\
\hline Aulacoseira islandica & WC-fr & Stephanodiscaceae & $\mathrm{WC}, \mathrm{EC}$ \\
\hline Azpeitia neocrenulata & WC-fr & Stephanopyxis nipponica & $\mathrm{WC}$ \\
\hline Campylosira cymbelliformis & WC, EC-fr & Raphoneidaceae & WC, EC, gr \\
\hline Coscinodiscus spp. & WC & Tabularia fasciculata & WC, EC, gr \\
\hline Cyclotella atomus & WC-fr & Thalassionema nitzschioides & WC-fr, EC, gr \\
\hline Cyclotella choctawhatcheeana & WC, EC, gr & Thalassionema pseudonitzschioides & EC-fr, gr \\
\hline Cyclotella litoralis & WC, EC-fr & Thalassiosira anguste-lineata & $\mathrm{WC}$ \\
\hline Cyclotella meneghiniana & WC-fr, EC & Thalassiosira eccentrica & $\mathrm{WC}, \mathrm{EC}$ \\
\hline Cyclotella scaldensis & WC-fr, EC-fr & Thalassiosira gessneri & WC-fr \\
\hline Cymatosira belgica & WC-fr, EC-fr & Thalassiosira gravida & WC \\
\hline Ditylum brightwellii & gr & Thalassiosira nordenskioeldii & WC \\
\hline Fragilaria crotonensis & WC-fr, EC & Thalassiosira oestrupii var. venrickae & WC-fr \\
\hline Fragilariopsis doliolus & WC & Thalassiosira pacifica & WC \\
\hline Gyrosigma fasciola & WC-fr, EC & Thalassiosira poroseriata & WC-fr \\
\hline Leptocylindrus danicus & $\mathrm{gr}$ & Thalassiosira punctigera & $\mathrm{EC}, \mathrm{gr}$ \\
\hline Leptocylindrus minimus & $\mathrm{WC}, \mathrm{EC}$ & Thalassiosira rotula & WC \\
\hline Mediopyxis helysia & gr & Thalassiosira tenera & $\mathrm{WC}, \mathrm{EC}$ \\
\hline Melosira moniliformis & $\mathrm{WC}, \mathrm{EC}, \mathrm{gr}$ & Thalassiosira trifulta & WC-fr \\
\hline Melosira varians & WC-fr, EC & Spore Chaetoceros debilis & $\mathrm{WC}, \mathrm{EC}, \mathrm{gr}$ \\
\hline Minidiscus chilensis & $\mathrm{EC}, \mathrm{gr}$ & Spore Chaetoceros diadema & $\mathrm{WC}, \mathrm{EC}$ \\
\hline Neodenticula seminae & WC & Spore Chaetoceros didymus & $\mathrm{WC}, \mathrm{EC}$ \\
\hline Odontella aurita & WC, EC, gr & Spore Chaetoceros lorenzianus & $\mathrm{WC}$ \\
\hline Opephora guenter-grassii & EC-fr, gr & Spore Stephanopyxis turris & WC \\
\hline Paralia longispina & EC-fr, gr & Spore Thalassiosira nordenskioeldii & $\mathrm{WC}, \mathrm{EC}$ \\
\hline
\end{tabular}




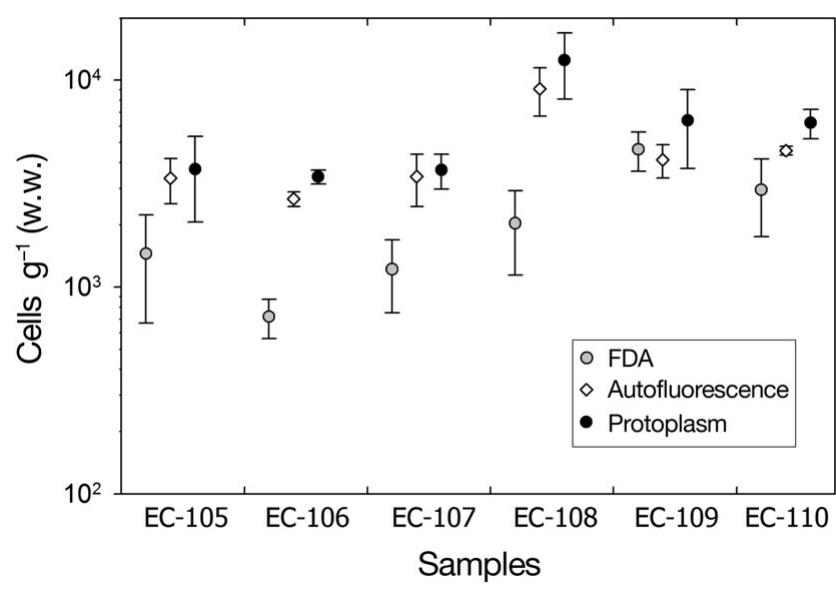

Fig. 5. Mean cell concentrations $( \pm \mathrm{SD}, \mathrm{n}=3$ or 4$)$ in samples taken on the Canadian east coast (EC) as determined by different indicators of cell viability: fluorescein diacetate (FDA), autofluorescence of the chlorophylls, and protoplasm integrity. See 'Results: Actual and effective propagule pressure' for statistical inferences

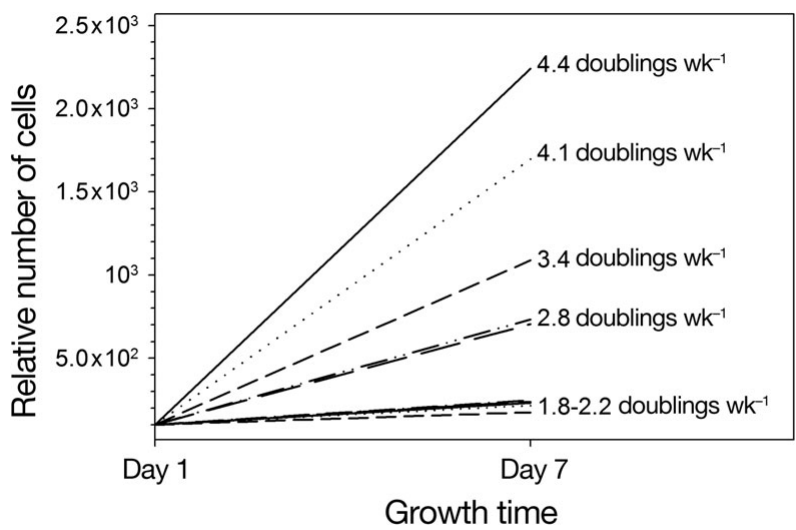

Fig. 6. Growth curves (and respective growth rates) for 10 ballast sediment samples counted using fluorescein diacetate (FDA), each represented by a different line, although lowest range corresponds to 5 lines roughly superimposed on each other. Starting point is standardized to 100 cells $\mathrm{g}^{-1}$ wet weight, the lowest range of potential inoculation found in all samples (preserved plus live) analyzed in the present study

tanks) or superior (Hallegraeff \& Bolch 1992, n = 343 tanks) to ours. High relative contributions of diatoms in the sediments probably mirror the composition of the assemblages most often found in the ballast waters, with or without offshore exchange (e.g. Zhang \& Dickman 1999, McCollin et al. 2007, Burkholder et al. 2007); except, perhaps, for those tanks that ballast in areas notably under freshwater influence in which cyanobacteria and chlorophytes may dominate (e.g. Olenin et al. 2000).

Diatom assemblages were a mixture of planktonic species (e.g. Asterionellopsis glacialis, Ditylum brightwellii, Pseudo-nitzschia spp., Thalassionema nitzschi- oides) and taxa commonly found in association with seafloor sediments in nature (e.g. Cymatosiraceae, Raphoneidaceae). Resting spores, mostly of Chaetoceros spp., were frequently found in ours as in other studies of ship ballast waters (Klein et al. 2009a) and sediments (Hallegraeff \& Bolch 1992). The following genera stood out in terms of recurrence and/or cell concentrations: Actinocyclus, Actinoptychus, Aulacoseira, Cyclotella, Chaetoceros spores, Melosira, Neodenticula, Paralia, Skeletonema, Thalassiosira, and Stephanodiscus. Some of these (Aulacoseira, Stephanodiscus), in association with the presence of the chlorophytes Pediastrum and Desmodesmus, indicate a strong and lasting contribution of freshwater biota. This is not surprising, since low salinity residues of ballast taken in brackish/freshwater ports have been found in tanks that underwent offshore exchange (e.g. Olenin et al. 2000, Villac et al. 2001, McCollin et al. 2007, Klein et al. 2009b).

Based on an inventory of diatoms documented for the eastern and western Canadian coastal waters (Mather et al. 2010), our preliminary list of potential (still confined in the tank) new records includes 18 species to the WC and 8 species to the EC (Table 4). If these species are found in the natural environment, the hypothesis of their recent introductions ought not to be accepted uncritically as the following examples illustrate. (1) Asterionellopsis glacialis and Thalassionema nitzschioides, known to occur in adjacent waters of the Pacific USA (Cupp 1943), could be (also) transported by currents. (2) Paralia longispina is a recently described species (Konno \& Jordan 2008) of largely unknown biogeography and potential for hosting cryptic diversity (M. MacGillivary pers. comm.); until now only a few routine investigations using electron microscopy have differentiated this species from the most often cited congener, P. sulcata. (3) Pseudo-nitzschia turgidula, a toxin producer, also requires electron microscopy for positive identification. Aulacoseira spp., Fragilaria crotonensis, Asterionella formosa, and Melosira varians are chiefly freshwater species (Wehr \& Sheath 2003) and thus good candidates to be classified as non-indigenous in coastal environments; nevertheless, as demonstrated by their records on the EC, the occurrence of Aulacoseira spp. and $M$. varians can be attributed to local freshwater input and temporary survival in brackish conditions commonly found in port areas. The large number of 'first records' undoubtedly also reflects the scarcity of baseline floristic data for these regions.

\section{Actual propagule pressure}

As a whole, only 36 and $60 \%$ of the ships investigated on the WC and EC, respectively, contained dia- 
toms detected by our methods. It is important to emphasize that 'undetectable' does not mean absent and that it follows that reduced risk does not mean 'no risk'. This is at the heart of the difficulty in establishing bioinvasion patterns, given the complexity superimposed by each step involved in the filter barrier paradigm (Carlton 1985). Early detection of NIS is a key component in bioinvasion risk assessments (Reaser et al. 2008) and a more in-depth discussion about the resolution power of our analysis, indicated in Fig. 1, is provided in the supplement at www-int-res.com/ articles/supp/m425p047_supp.pdf.

The data set of 118 samples from arrivals to Canadian ports during 2007 and 2008 represents a small sub-set of total ship arrivals. For comparison, estimated arrivals in a 12 mo period between 2006 and 2007 were 4122 in the WC and 3583 in the EC (B. V. Lo et al. unpubl. data). If the total concentration of cells detected in our study is extrapolated to $36 \%$ of arrivals to the WC and $60 \%$ to the EC, the amount of diatoms transported in ballast sediments during our 2-yr period would be equivalent to, respectively, $1 \times 10^{13}$ cells and $3.6 \times 10^{13}$ cells. This is a conservative approximation that considers only 1 tank per ship. The vast majority of the ships investigated were bulk carriers and oil tankers (Tables $1 \& 2$ ) equipped with several tanks of varying capacity, which indeed represent the largest contribution to ship traffic and volume of ballast transport in both regions (B. V. Lo et al. unpubl. data). Unfortunately, ship routes of these types of vessels are less consistent than those of general cargo and container ships, posing a challenge to bioinvasion risk assessment (Kaluza et al. 2010). In contrast, the more predictable routes of container ships would bring less ballast, but repeatedly from the same regional seed stock.

The Pacific and Atlantic coasts are each subject to particular ship traffics and will likely require different management practices. Our analysis indicates that all ship categories that reach the WC should receive the same level of concern (no statistical difference found) and, in comparison with the EC ships, the incoming flora seems to be more diverse and with a higher number of potential NIS. For the EC, the ICU ships represented a potential for a bioinvasion pattern based on more frequent events, though with consistently lower diatom cell concentrations whereas ICE and TOE ships showed a pattern of less frequent events, though of higher magnitude and less predictable. Such reasoning, based on the concept of propagule pressure with actual diatom concentrations, may support risk assessment plans in the ports of entry, which range from all ships being subject to management to a selective approach that takes into account different levels of risk posed by a given ship route (Gollasch et al. 2007, IMO 2007).
The suggestion that ballast water exchange has reduced the frequency of propagule pressure of diatoms accumulated in the sediments, especially in the $\mathrm{EC}$, is a welcomed result, although with 2 caveats. First, this does not mean that TOE and ICE ships should escape scrutiny, since a number of tanks from these ships still had high diatom concentrations. The efficiency of ballast water exchange is highly variable and depends, among other factors, on site of exchange and tank and ship design (Dickman \& Zhang 1999, McCollin et al. 2007, Taylor et al. 2007). Even for those tanks that exchange a minimum of $95 \%$ ballast water volume offshore in accordance with international and Canadian regulations (IMO 2004, Transport Canada 2006), this does not necessarily equate to $95 \%$ organism removal as the organisms are not homogeneously distributed in a tank (e.g. Carlton 1985, Rigby \& Hallegraeff 1994, Zhang \& Dickman 1999). Second, when ships are not able (thus not enforced) to comply with offshore exchange, as in intra-coastal voyages, ballast exchange is allowed in areas only 50 nautical miles from land and in waters 300 to $500 \mathrm{~m}$ deep (Transport Canada 2006). In such cases, a still unknown quantity of diatom propagules of unknown composition is being discharged (and possibly taken up) close to shelf areas, where favorable growth conditions may exist for coastal species. Indeed, there are known cases when the highest cell concentrations were found in tanks with recently exchanged coastal water (e.g. McCollin et al. 2007), similar to some of our ICE ships on the EC (e.g. EC-71, EC-83; Table 2). Although ballast water exchange seemed to have also decreased species richness in some of our sediment samples, interpretation of these results is more complex than for bulk cell concentrations and should be regarded with caution. Consider 2 ships, identical in tank design and in their efficiency of ballast water exchange offshore: At the beginning of the voyage they have equivalent concentration of cells, but very different species numbers. The same given amount of cells deballasted offshore may lead to distinct outcomes in terms of species richness left in the tank due to differences in the original assemblages.

\section{Effective propagule pressure}

Most of our dataset is based on preserved samples for which protoplasm integrity was the sole means of distinguishing live from dead cells. The comparison between indicators of cell viability showed that protoplasm integrity gives results that are not statistically different from autofluorescence, although marginally different from vital stain FDA. The possibility of false negatives in the FDA signal as found in other studies 
(see Garvey et al. 2007) suggests that, if this were taken into account, FDA might give results closer to those provided by the other methods. In any event, similar testing with a broader data set is required to further investigate this issue. It is not our intent to 'elect' the best indicator of viability, since each one of these methods has its own set of advantages and limitations (see 'Introduction'). For those involved in ballast management, however, assessment of viability is essential for compliance with regulatory practices (see Regulation D-2, IMO 2004) and access to live samples has become mandatory; thus the need to consider the use of vital stains in such cases (Reavie et al. 2010).

Actual growth is still a less disputable sign of viability. Viable diatoms have been found in ballast tanks, as demonstrated by incubation experiments with ballast waters (Subba Rao et al. 1994, Rhodes et al. 1998, Forbes \& Hallegraeff 2002, McCarthy \& Crowder 2000, Marangoni et al. 2001, Burkholder et al. 2007) and ballast sediments (Hallegraeff \& Bolch 1992, Kelly 1993, Pertola et al. 2006), although growth rate potentials had not been quantified before. In our case, the sum of all diatoms detected in the live samples at arrival was $5.4 \times 10^{9}$ cells (12 ICU ships calling on Saint John harbor within $2 \mathrm{wk}_{\text {; }}$ Table 2). If complete deballast of sediments and growth had been possible, local waters could have harbored $10^{10}$ to $10^{11}$ newcomers after $7 \mathrm{~d}$. Unlike some dinoflagellates, most diatoms do not require a dormancy period and, given favourable conditions, start asexual multiplication (normal growth state for most diatoms) within $24 \mathrm{~h}$ (McQuoid \& Hobson 1996). This exercise demonstrates that our earlier estimate of $8.7 \times 10^{12}$ cells arriving in ballast sediments to various ports on the EC in 2007 to 2008 is conservative. Indeed, a conservative approach is called for, considering that our laboratory culturing conditions represented ideal growth in an environment where grazers and other sources of losses were absent.

It is fair to assume that if the ballast water is treated during the voyage and complies with standards established by regulations that allow for deballast at the port, then the organisms found in suspension from the sediment would have also been treated and reduced in abundance. However, how much of the remaining sediment is re-suspended during the actual deballast due to pump operations, and inoculated into the environment at the receiving port, is still an important missing piece in the chain of events leading to NIS introductions. For the case of the port of Saint John exercise discussed above, if only $1 \%$ of the diatoms in the tank sediments were actually re-suspended and deballasted, given $7 \mathrm{~d}$ of growth, the environment might have harbored $10^{8}$ to $10^{9}$ newcomers. The unfortunate experience in the Great Lakes with unmanaged ballast for NOBOB ships clarified the importance of ballast sediments as a source of NIS seed stocks (Ricciardi 2001). And these seed stocks, according to our experiments, can comprise not only fast-growing species such as small diatoms with a high surface-to-volume ratio (e.g. Cyclotella choctawhatcheena, Miniduscus chilensis, Opephora guenter-grassii; Table 4), but also large-sized diatoms that were even below our detection level at first (Ditylum brightwellii, Leptocylindrus danicus, Mediopyxis helysia). The rapid response of large diatoms, after periods under unfavorable conditions inside a ballast tank, could be attributed to their capability of nitrogen storage in large vacuoles and the lack of physiological constraints to growth at very low light levels, as shown for some other large species in culture and in nature (Goldman \& McGillicuddy 2003, Litchman et al. 2009).

Diatoms can remain viable for long periods in the dark and at cold temperatures (ca. $5^{\circ} \mathrm{C}$ ). In fact, several species grew from ballast sediments that had been stored for 6 mo (Hallegraeff \& Bolch 1992) and from natural sediments stored for $4 \mathrm{yr}$ (Lewis et al. 1999). Diatoms show alternate modes of nutrition (mixotrophy), as may be the case of Nanofrustulum shiloi, which is found in ballast tanks (Klein et al. 2009b) but known among other diatoms in nature as well. At least 150 diatom species are known to produce resting spores or resting cells as a long-term survival strategy (McQuoid \& Hobson 1996) although we suspect that the list of those that form resting cells is highly underestimated, judging from the taxa that grew from ballast sediments (e.g. Asterionellopsis glacialis, Mediopyxis helysia, Pleurosigma/Gyrosigma ssp., several members of the family Raphoneidaceae) by us and others (Hallegraeff \& Bolch 1992, Kelly 1993, Waters et al. 2001), for which resting cells have not been reported in the literature.

\section{CONCLUSIONS}

We quantified diatoms in the sediments of ballast tanks of ships arriving to Canadian ports during 2007 to 2009 as ranging from non-detected to $10^{11}$ cells per tank. Diatom diversity was as high as 40 taxa per tank, including organisms in resting stages and cells that were supposedly growing vegetatively. Our estimates of propagule pressure indicated different bioinvasion patterns for the WC and EC, according to distinct ship categories. Upon recovery from the ballast sediments, in vitro growth rates ( 1.8 to 4.4 doublings $\mathrm{wk}^{-1}$ ) of these diatoms provided further insights into NIS growth potential in destination ports. As part of a wider survey of Canadian aquatic systems, the CAISN program, these assessments may be incorporated into conceptual and predictive models aiming to understand general trends in microbial 
bioinvasions mediated by shipping as well as supporting risk assessment plans in the ports of entry.

As we acknowledge existing challenges involved in supporting a bioinvasion hypothesis for microorganisms (e.g. inadequately known microbial diversity and geography, insufficient methods of detection), we observe that these challenges have already been met by the use of paleontological and molecular data for several micro-eukaryotes without any evidence that they may be non-representative and exceptional cases. In the meantime, cell concentrations found by this and other studies, even without species identification, should suffice to support management decision making, especially if one evokes facilitative interactions as a model to explain and predict bioinvasions. This 'meltdown model' (Ricciardi 2001, and references therein) states that ecosystems become more easily invaded as the cumulative number of species introductions increases. There is no need to identify all species in order to anticipate that the effects of NIS (or genetic lineages) of diatoms on the base of the food web will eventually project into other trophic levels.

Acknowledgements. This research was supported by the Canadian Aquatic Invasive Species Network and the Natural Sciences and Engineering Research Council of Canada. We thank all individuals that were part of CAISN sampling teams on the west and east coasts, J. Ehrman for electron microscopy expertise, E. Briski for providing total sediment estimates for tanks and ships sampled, B. V. Lo for sharing unpublished material about shipping traffic and ballast water operations at Canadian ports, and 3 anonymous reviewers for good suggestions and constructive criticism. Participation of the shipping companies was greatly appreciated.

\section{LITERATURE CITED}

Bailey SA, Duggan IC, Nandakumar K, MacIsaac HJ (2007) Sediments in ships: biota as biological contaminants. Aquat Ecosyst Health 10:93-100

Blanco J (1986) Separación de quistes de dinoflagellados en gradiente de densidad. Bol Inst Esp Oceanogr 3:81-84

Boalch G, Harbour D (1977) Unusual diatom off the coast of south-west England and its effect on fishing. Nature 269: 687-688

Bolch CJS (1997) The use of sodium polytungstate for the separation and concentration of living dinoflagellate cysts from marine sediments. Phycologia 36:472-478

Briski E, Bailey SA, Cristescu ME, MacIsaac HJ (2010) Efficacy of 'saltwater flushing' in protecting the Great Lakes from biological invasions by invertebrate eggs in ships' ballast sediment. Freshw Biol 55:2414-2424

Burkholder J, Hallegraeff G, Melia G, Cohen A and others (2007) Phytoplankton and bacterial assemblages in ballast water of US military ships as a function of port of origin, voyage time, and ocean exchange practices. Harmful Algae 6:486-518

Carlton JT (1985) Transoceanic and interoceanic dispersal of coastal marine organisms: the biology of ballast water. Oceanogr Mar Biol Annu Rev 23:313-371
Carlton JT (1996) Biological invasions and cryptogenic species. Ecology 77:1653-1655

Carlton JT, Geller JB (1993) Ecological roulette: the global transport of nonindigenous marine organisms. Science 261:78-82

Colautti RI, Grigorovich IA, MacIsaac HJ (2006) Propagule pressure: a null model for biological invasions. Biol Invasions 8:1023-1037

Cupp EE (1943) Marine plankton diatoms of the west coast of North America. Bull Scripps Inst Oceanogr 5:1-238

de Jonge VN (1979) Quantitative separation of benthic diatoms from sediments using density gradient centrifugation in the colloidal silica Ludox-TM. Mar Biol 51:267-278

> Dickman M, Zhang F (1999) Mid-ocean exchange of container vessel ballast water. 2: Effects of vessel type in the transport of diatoms and dinoflagellates from Manzanillo, Mexico, to Hong Kong, China. Mar Ecol Prog Ser 176: 253-262

Doblin MA, Drake LA, Coyne KJ, Rublee PA, Dobbs FC (2004) Pfiesteria species identified in ships' ballast water and residuals: a possible vector for introductions to coastal areas. In: Steidinger KA, Landsberg JH, Tomas CR, Vargo GA (eds) Harmful Algae 2002. Florida Fish and Wildlife Conservation Commission, Florida Institute of Oceanography, and Intergovernmental Oceanographic Commission of UNESCO, St. Petersburg, FA, p 317-319

> Drake LA, Doblin MA, Dobbs FC (2007) Potential microbial bioinvasions via ships' ballast water, sediment, and biofilm. Mar Pollut Bull 55:333-341

> Fernandes LF, Zehnder-Alves L, Bassfeld JC (2001) The recently established diatom Coscinodiscus wailesii (Coscinodiscales, Bacillariophyta) in Brazilian waters. I: Remarks on morphology and distribution. Phycol Res 49: 89-96

Forbes E, Hallegraeff GM (2002) Transport of potentially toxic Pseudo-nitzschia diatom species via ballast water. In: John J (ed) Proc 15th Int Diatom Symp 1998. Gantner, Koenigstein, p 509-520

- Franklin DJ, Brussaard CPD, Berges JA (2006) What is the role and nature of programmed cell death in phytoplankton ecology? Eur J Phycol 41:1-14

Galil BS, Hülsmann N (1997) Protist transport via ballast water-biological classification of ballast tanks by food interactions. Eur J Protistol 33:244-253

- Garvey M, Moriceau B, Passow U (2007) Applicability of the FDA assay to determine the viability of marine phytoplankton under different environmental conditions. Mar Ecol Prog Ser 352:17-26

Goldman JC, McGillicuddy DJ Jr (2003) Effect of large marine diatoms growing at low light on episodic new production. Limnol Oceanogr 48:1176-1182

> Gollasch S, David M, Voigt M, Dragsund E, Hewitt C, Fukuyo Y (2007) Critical review of the IMO international convention on the management of ships' ballast water and sediments. Harmful Algae 6:585-600

Guillard RRL (1973) Division rates. In: Stein JR (ed) Handbook of phycological methods. Culture methods and growth measurements. Cambridge Universtity Press, Cambridge

Hallegraeff GM, Bolch CJ (1992) Transport of diatom and dinoflagellate resting spores in ships' ballast water: implications for plankton biogeography and aquaculture. J Plankton Res 14:1067-1084

> Hamer JP, McCollin TA, Lucas IAN (2000) Dinoflagellate cysts in ballast tank sediments: between tank variability. Mar Pollut Bull 40:731-733

Hamer JP, Lucas IAN, McCollin TA (2001) Harmful dinofla- 
gellate resting cysts in ships' ballast tank sediments: potential for introduction into English and Welsh waters. Phycologia 40:246-255

Hasle GR (1978) The inverted-microscope method. In: Sournia A (ed) Phytoplankton manual. UNESCO, Paris, p 88-96

IMO (International Maritime Organization) (2004) International convention for the control and management of ships' ballast water and sediments. Bundesamt für Seeschifffahrt und Hydrographie, Hamburg. Available at: www.bsh.de/de/ Meeresdaten/Umweltschutz/Ballastwasser/Konvention_en. pdf

IMO (International Maritime Organization) (2007) Guidelines for risk assessment under regulation A-4 of the BWM Convention (G7) - Resolution MEPC.162(56). IMO, London. Available at www.imo.org/includes/blastDataOnly.asp/ data_id\%3D19689/162\%2856\%29.pdf

Kaczmarska I, LeGresley MM, Martin JL, Ehrman JM (2005) Diversity of the diatom genus Pseudo-nitzschia Peragallo in the Quoddy Region of the Bay of Fundy, Canada. Harmful Algae 4:1-19

Kaluza P, Kölzsch A, Gastner MT, Blasius B (2010) The complex network of global cargo ship movements. J R Soc Interface 7:1093-1103

Kat M (1982) Effects of fluctuating salinities on the development of Thalassiosira angstii, a diatom not observed before in the Dutch coastal area. J Mar Biol Assoc UK 62: 483-484

Kelly JM (1993) Ballast water and sediments as mechanisms for unwanted species introductions into Washington state. J Shellfish Res 12:405-410

Klein G, Kaczmarska I, Ehrman JM (2009a) The diatom Chaetoceros in ships' ballast waters-survivorship of stowaways. Acta Bot Croat 68:325-338

Klein G, MacIntosh K, Kaczmarska I, Ehrman JM (2009b) Diatom survivorship in ballast water during trans-Pacific crossings. Biol Invasions 5:1031-1044

Konno S, Jordan RW (2008) Paralia longispina sp. nov., an extant species from Palau and Haha-jima, western North Pacific. In: Likhoshway Y (ed) Proc 19th Int Diatom Symp. Biopress, Bristol, p 55-69

Lewis J, Harris ASD, Jones KJ, Edmonds RL (1999) Long-term survival of marine planktonic diatoms and dinoflagellates in stored sediment samples. J Plankton Res 21:343-354

Litchman E, Klausmeier CA, Yoshiyama K (2009) Contrasting size evolution in marine and freshwater diatoms. Proc Natl Acad Sci USA 106:2665-2670

Lockwood JL, Cassey P, Blackburn T (2005) The role of propagule pressure in explaining species invasions. Trends Ecol Evol 20:223-228

MacIsaac HJ, Grigorovich IA, Ricciardi A (2001) Reassessment of species invasions concepts: the Great Lakes basin as a model. Biol Invasions 3:405-416

Marangoni C, Pienaar RN, Sym SD (2001) Possible introduction of alien phytoplankton via shipping ballast water: a South African perspective. S Afr J Bot 67:465-474

> Martin JL, LeGresley MM (2008) New phytoplankton species in the Bay of Fundy since 1995. ICES J Mar Sci 65: 759-764

Mather L, MacIntosh K, Kaczmarska I, Klein G, Martin JL (2010) A checklist of diatom species reported (and presumed native) from Canadian coastal waters. Can Tech Rep Fish Aquat Sci 2881

> McCarthy HP, Crowder LB (2000) An overlooked scale of global transport: phytoplankton species richness in ships' ballast water. Biol Invasions 2:321-322

McCollin T, Shanks AM, Dunn J (2007) The efficiency of regional ballast water exchange: changes in phytoplankton abundance and diversity. Harmful Algae 6:531-546

McMinn A, Hallegraeff GM, Thomson P, Jenkinson AV, Heijnis $H$ (1997) Cyst and radionucleotide evidence for the recent introduction of the toxic dinoflagellate Gymnodinium catenatum into Tasmanian waters. Mar Ecol Prog Ser 161:165-172

McQuoid MR, Hobson LA (1996) Diatom resting stages. J Phycol 32:889-902

Medcof J (1975) Living marine animals in a ship's ballast water. Proc Natl Shellfish Ass 65:11-12

> Olenin S, Gollasch S, Jonusas S, Rimkute I (2000) En-route investigations of plankton in ballast water on a ship's voyage from the Baltic Sea to the open Atlantic coast of Europe. Internat Rev Hydrobiol 85:577-596

> Pertola S, Faust MA, Kuosa H (2006) Survey on germination and species composition of dinoflagellates from ballast tanks and recent sediments in ports on the South Coast of Finland, North-Eastern Baltic Sea. Mar Pollut Bull 52: 900-911

> Reaser JK, Meyerson LA, Holle BV (2008) Saving camels from straws: how propagule pressure-based prevention policies can reduce the risk of biological invasion. Biol Invasions 10:1085-1098

Reavie ED, Cangelosi AA, Allinger LE (2010) Assessing ballast water treatments: evaluation of viability methods for ambient freshwater microplankton assemblages. J Gt Lakes Res 36:540-547

Rhodes L, Scholin CA, Garthwaite I, Haywood A, Thomas A (1998) Domoic acid producing Pseudo-nitzschia species educed by whole cell DNA probe-based and immunochemical assays. In: Reguera B, Blanco I, Fernández M, Wyatt T (eds) Harmful algae. Xunta de Galicia and IOC of UNESCO, Paris

Ricciardi A (2001) Facilitative interactions among aquatic invaders: is an 'invasional meltdown' occurring in the Great Lakes? Can J Fish Aquat Sci 58:2513-2525

Rigby G, Hallegraeff GM (1994) The transfer and control of harmful marine organisms in shipping ballast water: behaviour of marine plankton and ballast water exchange trials on the MV 'Iron Whyalla'. J Mar Env Eng 1: 91-110

Ruiz GR, Fofonoff PW, Carlton JT, Wonham MJ, Hines AH (2000) Invasion of coastal marine communities in North America: apparent patterns, processes, and biases. Annu Rev Ecol Syst 31:481-531

Scholin CA (1998) Morphological, genetic and biogeographic relationships of Alexandrium tamarense, A. catenella and A. fundyense. In: Anderson DM, Hallegraeff GM, Cembella AD (eds) The physiological ecology of harmful algal blooms. Springer-Verlag, Heidelberg, p 13-27

Shaw AB (1964) Time in stratigraphy. McGraw-Hill, New York, NY

Smayda TJ (2007) Reflections on the ballast water dispersalharmful algal bloom paradigm. Harmful Algae 6:601-622

Subba Rao DV, Sprules WG, Locke A, Carlton JT (1994) Exotic phytoplankton from ships' ballast waters: risk of potential spread to mariculture sites on Canada's East Coast. Can Data Rep Fish Aquat Sci 937:1-51

Taylor MD, MacKenzie LM, Dodgshun TJ, Hopkins GA, de Zwart EJ, Hunt CD (2007) Trans-Pacific shipboard trials on planktonic communities as indicators of open ocean ballast water exchange. Mar Ecol Prog Ser 350:41-54

Transport Canada (2006) Ballast water control and management regulations (SOR/2006-129). Dept of Justice Canada, Ottawa. Available at www.tc.gc.ca/eng/acts-regulations/ regulations.htm 
Veldhuis MJW, Kraay GW, Timmermans KR (2001) Cell death in phytoplankton: correlation between changes in membrane permeability, photosynthetic activity, pigmentation and growth. Eur J Phycol 36:167-177

Villac MC, Persich G, Fernandes L, Paranhos R and others (2001) Ballast water exchange: testing the dilution method (Petrobrás, Brazil). In: Hallegraeff GM, Blackburn SI, Bolch CJ, Lewis RJ (eds) Harmful algal blooms 2000. International Oceanographic Commission, Paris, p 470-473

Waters R, Haigh N, Whyte JNC, Levings C (2001) Synoptic investigation for algae in ballast water and sediments of

Editorial responsibility: Hans Heinrich Janssen, Oldendorf/Luhe, Germany ships using selected British Columbia ports. Can Data Rep Fish Aquat Sci 1083:1-19

Wehr JD, Sheath RG (2003) Freshwater algae of North America. Academic Press, San Diego, CA

Wonham MJ, Lewis MA, MacIsaac HJ (2005) Minimizing invasion risk by reducing propagule pressure: a model for ballast water exchange. Front Ecol Environ 3:473-478

Zhang F, Dickman M (1999) Mid-ocean exchange of container vessel ballast water. 1: Seasonal factors affecting the transport of harmful diatoms and dinoflagellates. Mar Ecol Prog Ser 176:243-251

Submitted: June 4, 2010; Accepted: December 14, 2010 Proofs received from author(s): March 5, 2011 